\title{
Redox Cycling for SOFC Accelerated Degradation
}

\author{
Daria Vladikova ${ }^{1}$, Blagoy Burdin $^{1}$, Asrar Sheikh ${ }^{1}$, Paolo Piccardo ${ }^{2}$, Milena Krapchanska ${ }^{1}$, and Dario Montinaro ${ }^{3}$ \\ ${ }^{1}$ Institute of Electrochemistry and Energy Systems - Bulgarian Academy of Sciences, 10 Acad. G. Bonchev, \\ 1113 Sofia, Bulgaria \\ ${ }^{2}$ Dipartimento di Chimica e Chimica Industriale - University of Genova, via Dodecaneso 31, I-16146 Genoa, Italy \\ ${ }^{3}$ SOLIDpower S.p.A, Viale Trento 117, 38017, Mezzolombardo, Italy
}

\begin{abstract}
This work aims at development of Accelerated Stress Tests for SOFC via artificial aging of the fuel electrode applying chemical and electrochemical (hydrogen starvation) redox cycling. In principle the degradation processes follows that of calendar aging (Ni coarsening and migration), but in addition it can bring to irreversible damages caused by the development of cracks at the interface anode/electrolyte due to the expansion/shrinkage of the Ni network. The challenge is to introduce conditions which will prevent the formation of cracks which can be done by partial oxidation. The advantage of the proposed methodology is that a mild level of oxidation can be regulated by direct impedance monitoring of the Ni network resistance changes during oxidation/reduction. Once the redox cycling conditions are fixed on bare anode and checked on anode/electrolyte sample for eventual cracks, the procedure can be introduced for AST in full cell configuration. The developed methodology is evaluated by comparative impedance analysis of artificially aged and calendar aged button cells. The results for 20 redox cycles which can be performed for 24 hours are comparable with those obtained for about 1600 hours operation in standard conditions which ensures more than 50 times acceleration.
\end{abstract}

\section{Introduction}

Among fuel cells SOFC is an emerging technology for the efficient production of electricity [1] and hydrogen [2] implying low $\mathrm{CO}_{2}$ emissions [1]. Moreover, the possibility of being operated with different fuels [3] and in two modes - fuel cell and steam electrolysis, makes them perspective [2]. The SOFC technology is still away from commercialization mainly due to the problem of durability and lifetime [4]. Currently the lifetime requirement for SOFC is at least 40,000 hours [5], but testing for such long lifetimes is not viable. This problem can be overcome by the introduction of Accelerated Stress Tests (AST), which should ensure the investigation of long term phenomena in a shorter time.

This work aims at presenting an approach for AST based on artificial redox cycling of the anode in cell configuration before operation. Principally the same approach can be applied also for stack configuration. There are intensive studies of the anode degradation, since

Corresponding author: d.vladikova@iees.bas.bg it influences strongly the durability of the fuel cell. The most often used anode material is Nickel-yttria stabilized zirconia (Ni-YSZ) cermet. The anode is a multifunctional component which has high catalytic activity and electronic conductivity coming from the $\mathrm{Ni}$ network, optimized porosity ensuring the fuel input and the exhaust water output combined with strong mechanical stability, since it is most often used as cell support.

The main degradation of the anode during operation comes from the microstructural changes in the $\mathrm{Ni}$ network, due to both $\mathrm{Ni}$ agglomeration resulting in a phase coarsening and migration and volatilization changing the Ni distribution in the electrode. The Ni mean particle diameter increases due to the sintering of the smaller particles. The global effect is decrease of the triple phase boundaries (TFB) and of the Ni/gas specific surface area [6-20]. The migration over long distances can bring to Ni depletion near the electrolyte interface [8].

During long term operation the fuel electrode degrades due to Ni re-oxidation that causes microstructural changes $[21,22]$ that bring to accelerated degradation. This 
phenomenon can be caused by leakage, fuel starvation, increased oxygen partial pressure, accidental switch off, etc. The repetitive changes of $\mathrm{Ni}$ volume damage the cermet structure in two directions: (i) reduction of the TPB density due to accelerated $\mathrm{Ni}$ coarsening and (ii) production of cracks at the electrode/electrolyte interface [23-28]. The degradation can be evaluated by electrochemical testing followed by microstructural post mortem characterization based on comparative analysis between pristine and cycled samples. Dynamic in situ analyses recording the changes in the microstructure exposed to different redox conditions are also reported, however, they are performed in conditions which strongly differ from the operating environment [28-31]. Most often the chemical oxidation is performed in a furnace at high temperature and enough long time which brings to oxidation of the entire Ni network. There are some studies where partial oxidation is carried out [32] which report that when the oxidation of about $25 \%$ at $800^{\circ} \mathrm{C}$, no cracks are observed at the interface electrode/electrolyte. At lower temperatures the deepness of oxidation with no cracks formation could be even higher.

The analysis of the degradation caused by redox cycling shows that this approach which also causes $\mathrm{Ni}$ coarsening and migration can be used as a tool for accelerated degradation. However, the Accelerated Stress Tests should cause changes of the system similar to those obtained during calendar aging, i.e. the redox cycling conditions should prevent from cracking at the electrode/electrolyte interface which can be achieved by partial re-oxidation.

The challenge of the redox cycling approach is the governance of the process which should reproduce standard aging. This work proposes a method for artificial aging via redox cycling which can be governed and finetuned applying impedance monitoring of the oxidation level. Two approaches are selected: (i) chemical oxidation which starts from the outer part of the anode and influences the whole volume of the fuel electrode and (ii) electrochemical redox cycling via hydrogen starvation which localizes the redox cycling area in the vicinity of the interface electrode/electrolyte.

\section{Experimental}

The chemical oxidation is performed by consecutive change of the anode compartment gas flow from $\mathrm{N}_{2}+\mathrm{H}_{2}$ blend to air. A three-step procedure is applied:
- The redox cycling conditions which should determine the oxidation deepness are defined on experiments performed on bare anode mounted between two Pt nets [33]. This configuration ensures direct monitoring of the $\mathrm{Ni}$ network formation and changes during oxidation by impedance measurements of its resistance which has the typical for metallic conductivity inductive behavior. Fig. 1 shows a selected change of the Ni network resistance during oxidation. For ensuring partial oxidation the level of oxidation should not change the inductive behavior of the impedance which guarantees that the Ni network is not totally destroyed (Fig. 1). It should be noted that the absolute value of the $\mathrm{Ni}$ network resistance in the anode matrix is much lower than the measured one which includes also the ohmic resistance of the test rig. However, this parameter is very sensitive to the changes of the $\mathrm{Ni}$ network in respect to oxidation and can be used as internal standard for governing and monitoring of the process. Once the oxidation conditions are selected, high level of reproducibility is ensured (Fig. 1). They are further used for the redox cycling experiments in cell configuration. The level of aging is controlled by the number of redox cycles.

- The selected redox cycling regime is applied on anode/electrolyte sample for checking the interface anode/electrolyte which should not be influenced by the aging conditions and cycling. In this configuration (as well as in full cell) the $\mathrm{Ni}$ oxidation/reduction cannot be any more directly monitored and the measured impedance registers the effect of the governed oxidation/reduction on the total behavior of the investigated configuration.

- The final stage is the redox cycling on full cell.

The monitoring of the level of aging is performed by measurements of current voltage $(i-V)$ curves after selected number of redox cycles and analysis of the impedance diagrams measured after every cycle at OCV (Fig. 2) and periodically in different working points. After the final redox cycle post mortem analysis for microstructural characterization is also performed. 


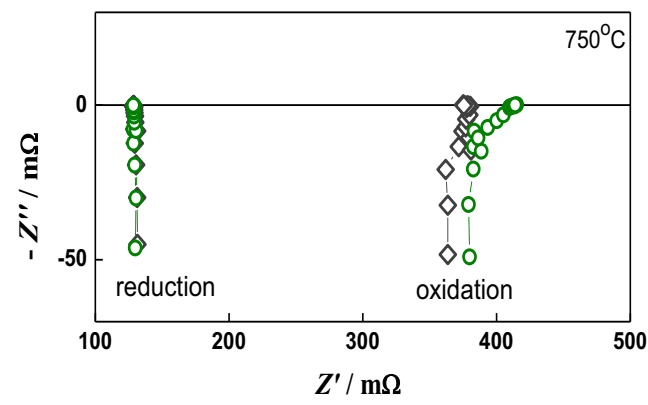

Fig. 1. Bare anode during redox cycling: two consecutive redox cycles - Cycle $7(\diamond)$ and Cycle $8(0)$.

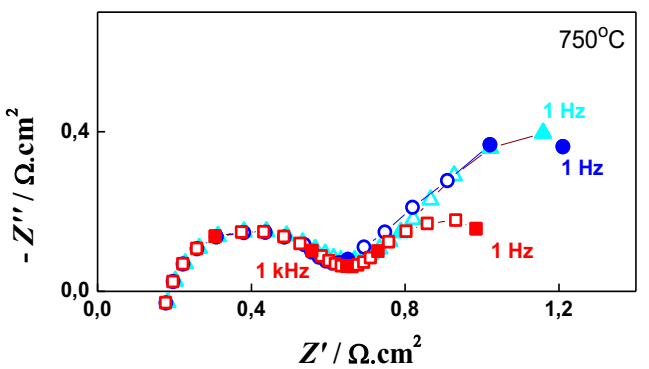

Fig. 2. Redox cycling of button cell at OCV: Oxidation $1(\triangle)$, Oxidation $6(\bullet)$, Reduction $6(\bullet)$.

The chemical redox cycling was carried out on button cells at $750^{\circ} \mathrm{C}$. More detailed information about the redox cycling procedure is described in [33].

The electrochemical redox cycling was performed directly on button cell configuration under load at $800^{\circ} \mathrm{C}$ the temperature of the initial reduction. On the cathode side there is constant air gas flow. On the anode side the selected blend of hydrogen and nitrogen is periodically replaced with pure nitrogen which is accompanied by voltage drop.

The sample configurations were prepared by SOLIDpower according to a technological procedure which is subjected to proprietary information: NiO-YSZ anode pellets (bare anode) with diameter $20 \mathrm{~mm}$ and thickness $250 \mu \mathrm{m}$; anode/electrolyte with the same anode and $10 \mu \mathrm{m}$ thick electrolyte $\left(8 \mathrm{~mol} \% \mathrm{Y}_{2} \mathrm{O}_{3}\right.$ stabilized zirconia) with GDC barrier layer; anode supported button cell with the same anode/electrolyte and oxygen electrode $(\mathrm{La}, \mathrm{Sr})(\mathrm{Co}, \mathrm{Fe}) \mathrm{O}_{3-\delta}$ (LSCF) perovskite with active surface area $0,28 \mathrm{~cm}^{2}$ and $(\mathrm{La}, \mathrm{Sr}) \mathrm{CoO}_{3-\delta}$ (LSC) layer on top for efficient current collection.

The test rig consists of a completely ceramic housing. The cell is sealed on the cathode side by ceramic paste (Ceramabond) following the procedure of the producer (Aremco products Inc). The testing was performed at $750^{\circ} \mathrm{C}$ and gas flows: air 435,7 Nml. $\mathrm{min}^{-1} \cdot \mathrm{cm}^{-2}$ and hydrogen $102,9 \mathrm{Nml} \cdot \mathrm{min}^{-1} \cdot \mathrm{cm}^{-2}$.
The impedance measurements were carried out on IVIUM CompactStat in a frequency range from $1 \mathrm{MHz}$ down to $1 \mathrm{~Hz}$ with density 5 points/decade in the temperature range from 22 to $800^{\circ} \mathrm{C}$ and amplitude of the AC signal depending on the impedance of the sample. A furnace with $\mathrm{DC}$ power supply and temperature drift during measurements less than $0,5^{\circ} \mathrm{C}$ ensures reproducible data with high quality. For the redox cycling experiments $\mathrm{Pt}$ meshes were used for contacts which makes the system stable in both oxidizing and reducing atmosphere.

Post mortem microstructure and porosity analysis were performed on Scanning Electron Microscope (SEM) Zeiss EVO 40 with acceleration voltage of $20 \mathrm{kV}$, equipped with an energy dispersive X-ray spectroscope (EDXS Pentafet). SEM BSE pictures with magnification 5000x were collected for quantitative image analyses and treated with Zeiss Axiovision software to estimate the porosity and Ni crystals volume fraction.

\section{Results and discussion}

\section{1. Chemical redox cycling}

The chemical aging of button cells via redox cycling was performed in two regimes that ensure partial oxidation: Regime 1 with 2 times increase of the initial resistance of the Ni network and Regime 2 with 4 times increase. The two selected oxidation depths do not change the inductive behavior of the bare anode impedance diagrams during oxidation which shows that the $\mathrm{Ni}$ network is not destroyed, i.e. that partial oxidation is kept (Fig. 1).

SEM images register $\mathrm{Ni}$ coarsening after 20 redox cycles of bare anode performed according to Regime 1 . Since the Ni grains have irregular shape, their size is presented as surface area $\left(\mu \mathrm{m}^{2}\right)$. The comparison of the distribution of pristine (reduced) anode and the aged one shows more irregular distribution with a tendency for rearrangement and increase of the fraction with larger grains for the redox cycled sample (Fig. 3).

The most challenging moment in the AST performance by redox cycling is the governing of the degradation level. On this stage a comparison with calendar aged cells based on impedance measurements is applied. The samples are prepared by the same technology and have the same composition. However, the information is selected from experiments performed in different operating conditions and test benches. Especially for impedance analysis the diagrams depend on the selected 
working point (Fig. 4). That is why the comparison was made based on the Area Specific Resistance (ASR) change in percentage (\%) after a definite number of cycles. Table 1 presents a summary of the experimental results performed applying Regime 2, while Table 2 gives similar information for calendar aging reaching 1200 hours.

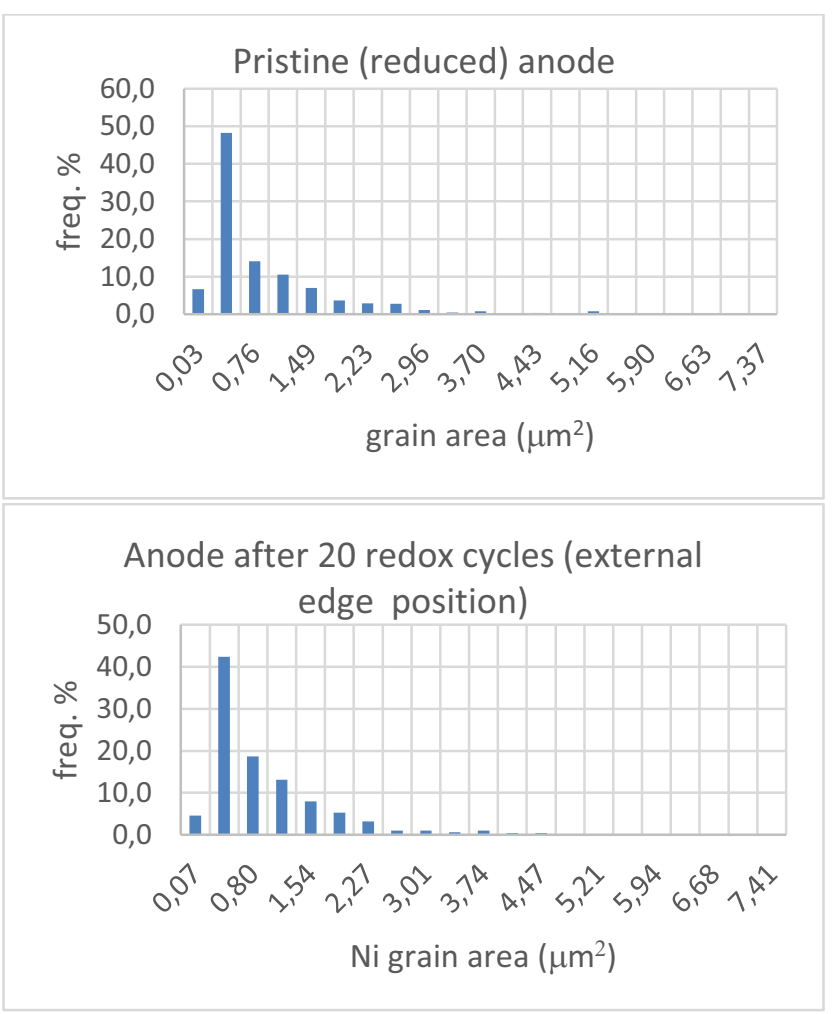

Fig. 3. Ni grain size distribution of bare anode before and after 20 redox cycles presented as grain area $\left(\mu \mathrm{m}^{2}\right)$.

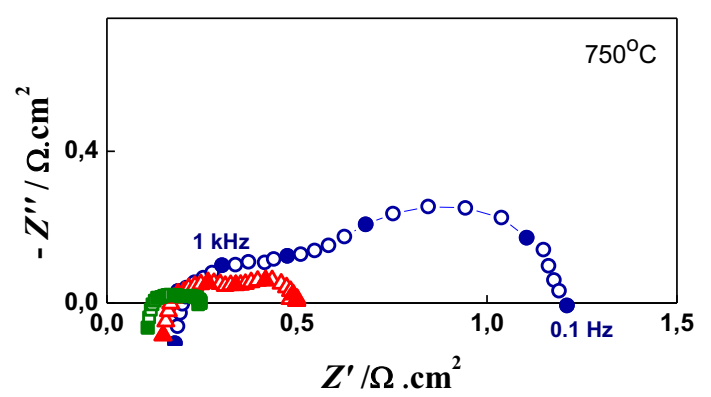

Fig. 4. Impedance diagrams of button cell recorded before redox cycling at 3 Working points: $\left.\mathrm{OCV}(\bullet) ; 0,11{\mathrm{~A} . \mathrm{cm}^{-2}}_{(\boldsymbol{\Delta})}\right) ; 0,29$ A.cm ${ }^{-2}(\square)$.

The experimental results show that between the $1^{\text {st }}$ and the $6^{\text {th }}$ redox cycle the ohmic resistance of the cell decreases (Fig. 5, Table 1) which is typical for the first 1000 hours of calendar aging, as it is presented in Fig. 6 and Table 2. Although the total resistance does not increase drastically and even may decrease (Table 2 - 600 hours), the increase of the polarization resistance is significant. Further and more detailed comparative analysis of the impedance data is under performance for extraction of additional information about the aging caused by the cell anode. The semiquantitative comparison between the data presented in Tables 1 and 2 can bring to the conclusion that the 20 redox cycles performed by Regime 2 can be compared with calendar aging exceeding 1200 hours. If we accept that the accelerated aging corresponds to about 1600 hours calendar operation, and taking into account that the performance of the 20 cycles needs 3 working days, i.e. about 24 hours, the acceleration factor could be evaluated on 66 which is very promising result. For more precise calculations, the number of redox cycles should be further increased.

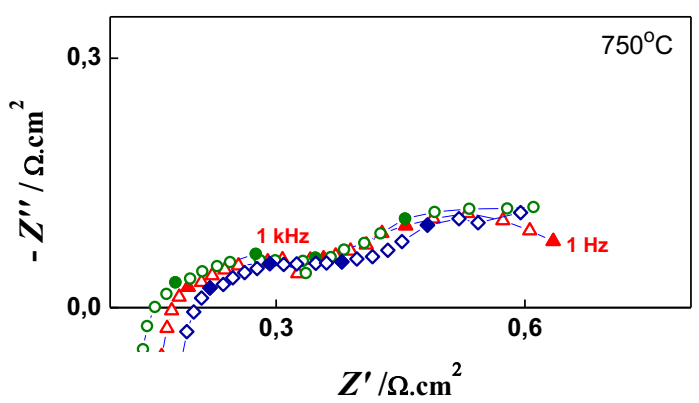

Fig. 5. Impedance diagrams of button cell at OCV during redox cycling: reduction $1(\mathbf{\Delta})$; reduction $6(\bullet)$; reduction $8(\bullet)$.

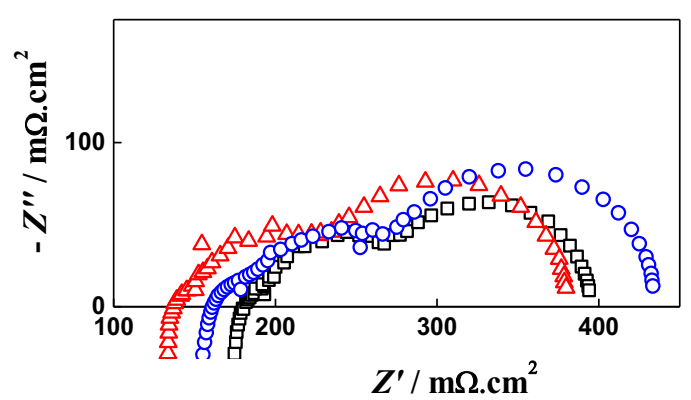

Fig. 6. Impedance spectra of calendar aged cell operated 1200 hours: 0h ( $\square)$; 600h ( $\Delta)$; 1200h (०).

\section{2. Electrochemical redox cycling via hydrogen starvation}

In respect to the electrochemical redox cycling, preliminary experiments were performed on button cell operated at $180 \mathrm{~mA} . \mathrm{cm}^{-2}$ by replacing the $\mathrm{H}_{2}$ gas flow 
with $\mathrm{N}_{2}\left(435,7 \mathrm{ml} \cdot \mathrm{min}^{-1} \cdot \mathrm{cm}^{-2}\right)$ for $480 \mathrm{sec}$., divided in 3 cycles of $160 \mathrm{sec}$. During every cycle the OCV was left to decrease down to $100 \mathrm{mV}$ thus introducing conditions of hydrogen starvation in the reaction area. After every cycle, due to diffusion of hydrogen from the neighbouring regions, the OCV was increasing. After the last cycle it was established at $716 \mathrm{mV}$. The anode reduction takes place in the first 2 minutes when the cell resistance sharply decreases and OCV jumps from 716 up to 1040 $\mathrm{mV}$. In the next 28 minutes, the polarization resistance slightly increases, which may be related to the release of the extra water formed during the reduction and the OCV reaches its initial value $(1120 \mathrm{mV})$. The cell impedance before, during and after electrochemical oxidation is presented in Fig. 7 and Table 1. The comparison between the initial and final state shows high level of degradation (about 100\% increase of the polarization resistance) which is confirmed also by the break of the sample in the end of the experiment. The results confirm the applicability of the electrochemical reoxidation. However, the experimental conditions should be adjusted towards those obtained by the chemical reduction in respect to oxidation depth which should not bring to cracks and delamination at the anode/electrolyte interface. A more precise procedure and criterion for oxidation depth, i.e. for level of hydrogen deficiency are under development.

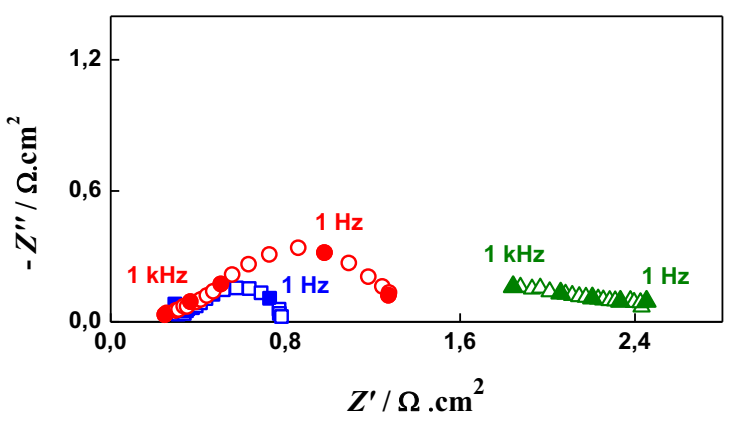

Fig. 7. Impedance diagrams of cell subjected to electrochemical redox cycling: before oxidation $(\square)$, end of oxidation $(\triangle)$, after 30 minutes reduction $(\circ)$.

Table 1. Chemical and electrochemical aging via redox cycling.

\begin{tabular}{|c|c|c|c|c|c|c|c|c|c|c|c|}
\hline \multirow{3}{*}{$\begin{array}{l}\text { Para } \\
\text { me } \\
\text { ter }\end{array}$} & \multicolumn{7}{|c|}{$\mathrm{R}\left(\mathrm{m} \Omega . \mathrm{cm}^{2}\right)$} & \multicolumn{4}{|c|}{ \% Change (vs. 0 cycles) } \\
\hline & $\begin{array}{c}0 \\
\text { cycles }\end{array}$ & $\begin{array}{c}6 \\
\text { cycles }\end{array}$ & $\begin{array}{c}0 \\
\text { cycles }\end{array}$ & $\begin{array}{c}7 \\
\text { cycles }\end{array}$ & $\begin{array}{c}20 \\
\text { cycles }\end{array}$ & $\begin{array}{c}0 \\
\text { cycle }\end{array}$ & $\begin{array}{c}1 \\
\text { cycle }\end{array}$ & $\begin{array}{c}6 \\
\text { cycles }\end{array}$ & $\begin{array}{c}7 \\
\text { cycles }\end{array}$ & $\begin{array}{c}20 \\
\text { cycles }\end{array}$ & $\begin{array}{c}1 \\
\text { cycle }\end{array}$ \\
\hline & $* *$ & $* *$ & * & $*$ & $*$ & $* * *$ & $* * *$ & $* *$ & $*$ & $*$ & $* * *$ \\
\hline$R_{\Omega}$ & 174,2 & 156,5 & 58,7 & 59,8 & 63,5 & 288,4 & 254,8 & $-10,2$ & $+1,9$ & $+8,2$ & $-11,7$ \\
\hline$R_{\mathrm{p}}$ & 568,1 & 666,2 & 59,8 & 39,7 & 42,5 & 492,8 & 1016,4 & $+17,3$ & $+16,4$ & $+24,5$ & $+106,3$ \\
\hline$R_{\mathrm{T}}$ & 742,3 & 822,7 & 92,8 & 99.5 & 106,0 & 781,2 & 1271,2 & $+10,8$ & $+7,2$ & $+14,2$ & $+62,7$ \\
\hline
\end{tabular}

$* i=510 \mathrm{~mA} . \mathrm{cm}^{-2}$

** OCV

$* * * \mathrm{H}_{2}$ starvation $\left(i=180 \mathrm{~mA} \cdot \mathrm{cm}^{-2}\right)$

Table 2. Calendar aging of button cell $\left(i=500 \mathrm{~mA} \cdot \mathrm{cm}^{-2}\right)$.

\begin{tabular}{|c|c|c|c|c|c|}
\hline \multirow[t]{2}{*}{ Parameter } & \multicolumn{3}{|c|}{$R\left(\mathrm{~m} \Omega . \mathrm{cm}^{2}\right)$} & \multicolumn{2}{|c|}{ \% Change (vs. 0 pristine sample) } \\
\hline & $0 h$ & $600 \mathrm{~h}$ & $1200 \mathrm{~h}$ & $600 \mathrm{~h}$ & $1200 \mathrm{~h}$ \\
\hline$R_{\Omega}$ & 180,6 & 137,0 & 160,2 & $-14,1$ & $-11,4$ \\
\hline$R_{\mathrm{p}}$ & 212,8 & 242,8 & 272,8 & 14,1 & 28,2 \\
\hline$R_{\mathrm{T}}$ & 393,4 & 393,4 & 433,0 & $-3,5$ & 10,0 \\
\hline
\end{tabular}




\section{Conclusions}

The developed procedure for accelerated degradation via artificial aging of the anode by chemical redox cycling confirms the applicability of the approach, which shows very high level of acceleration. The selected oxidation depths are reasonable and well reproducible. The efforts should be concentrated on the correlation between the redox cycles and the degradation level for which additional comparative studies with calendar aged cells are needed. For better comparison with field tests, button cells are produced from aged stacks. They will be tested in the same testing conditions, including equipment. The microstructural changes are also reliable information source which will be used more intensively. On this stage of development, the procedure demonstrates more than 50 times acceleration of the degradation which determines the artificial aging of the anode via redox cycling as a powerful tool for accelerated stress tests.

\section{Acknowledgements}

The research leading to these results received funding from the Fuel Cells and Hydrogen 2 Joint Undertaking under grant agreement № 825027. This Joint Undertaking receives support from the European Union's Horizon 2020 research and innovation program and Hydrogen Europe. The experiments were performed with equipment supported by the Bulgarian Ministry of Education and Science under the National Roadmap for Research Infrastructure 2017-2023 "Energy storage and hydrogen energetics (ESHER)", approved by DCM № $354 / 29.08 .2017$.

\section{References}

1. E. Pahon, N. Yousfi Steiner, S. Jemei, D. Hissel, M.C. Pẻra, K. Wang, P. Moçoteguy, Int. J. Hydrogen Energy, 2016, 41, 13678.

2. J. Laurencin, M. Hubert, D. Ferreira Sanchez, S. Pylypko, M. Morales, A. Morata, B. Morel, D. Montinaro, F. Lefebvre-Joud, E. Siebert, Electroc. Acta, 2017, 241, 459.

3. Y. Heo, J. Lee, S. Lee, T. Lim, S. Park, R. Song, C. Park, D. Shin, Int. J. Hydrogen Energy, 2011, 36, 797.

4. A. Hagen, J. Hogh, R. Barfod, J. Power Sources, 2015, 300, 223.
5. A. Ploner, A. Hagen, A. Hauch, J. Power Sources, 2018, 395, 379.

6. S. J. Kim, M. Choi, M. Park, H. Kim, J. Son, J. Lee, B. Kim, H. Lee, S. Kim, K. J. Yoon, J. Power Sources, 2017, 360, 284.

7. R. Vaßen, D. Simwonis and D. Stöver, J. Materials Science, 2001, 36(1), 147.

8. M. Ananyev, D. Bronin, D. Osinkin, V. Eremin, R. Steinberger-Wilckens, L.G.J. de Haart, J. Mertens, J. Power Sources, 2015, 286, 414.

9. P. Tanasini, M. Cannarozzo, P. Costamagna, A. Faes, J. Van Herle, A. Hessler-Wyser, C. Comninellis, Fuel Cells, 2009, 9(5), 740.

10. M. Hubert, J. Laurencin, P. Cloetens, J. Mougin, D. Ferreira Sanchez, S. Pylypko, M. Morales, A. Morata, B. Morel, D. Montinaro, E. Siebert, F. Lefebvre-Joud, ECS Transactions, 2017, 78, 3167.

11. J. Villanova, J. Laurencin, P. Cloetens, P. Bleuet, J. Delette, H. Suhonen, F. Usseglio-Viretta, J. Power Sources, 2013, 243, 841.

12. M. Hubert, J. Laurencin, P. Cloetens, B. Morel, J. Power Sources, 2018, 397, 240.

13. R. Spotorno, T. Ferrari, C. Nicolella, P. Piccardo, Proceedings of the 12th European SOFC \& SOE Forum, 5-8 July 2016, Lucerne/Switzerland, B1216.

14. M. Hubert, J. Laurencin, P. Cloetens and J. Mougin, ECS Transactions, 2017, 78(1), 3167.

15. A. Hauch, M. Mogensen, A. Hagen, 2011, 192(1), 547.

16. F. Monaco, M. Hubert, J. Vulliet, J. Ouweltjes, D. Montinaro, P. Cloetens, P. Piccardo, F. Lefebvre-Joud, J. Laurencin, J. Electrochemical Society, 2019, 166(15), F1229.

17. M. Trini, A. Hauch, S. De Angelis, X. Tong, P. Vang Hendriksen, M. Chen, J. Power Sources, 2020, 450, 227599.

18. G. Rinaldi, A. Nakajo, P. Caliandro, L. Navratilova, ECS Transactions, 2019, 91, 641.

19. M. Laguna-Bercero, J. Power Sources, 2012, 203, 4 .

20. A. Faes, A. Hessler-Wyser, D. Presvytes C. Vayenas, J. Van Herle, Fuel Cells, 2009, 9(6), 841.

21. A. Nakajo, Z. Wuillemin, J. Van Herle, D. Favrat, J. Power Sources, 2009, 193(1), 203.

22. A. Nakajo, Z. Wuillemin, J. Van Herle, D. Favrat, J. Power Sources, 2009, 193(1), 216.

23. A. Nakajo, A. Kiss, A. Cocco, W. Harris, M. DeGostin, F. Greco, G. Nelson, A. Peracchio, B. Cassenti, A. Deriy, S. Wang, Y. Chen-Wiegart, J. Wang, J. Van Herle, W. Chiu, ECS Transactions, 2015, 68(1), 1069. 
24. M. Pihlatie, A. Kaiser, M. Mogensen, M. Chen, Solid State Ionics, 2011, 189, 82.

25. D. Waldbillig, A. Wood, D. Ivey, J. Power Sources, 2005, 145, 206.

26. Y. Nakagawa, K. Yashiro, K. Sato, T. Kawada, J. Mizusaki, ECS Transactions, 2007, 7, 1373.

27. D. Sarandaridis, R. Rubkin, A. Atkinson, ECS Transactions, 2007, 7, 1491.

28. J. Laurancin, V. Roche, C. Jaboutian, I. Kieffer, J. Mougin, M. Steil, Int. J. Hydrogen Energy, 2012, 37, 12557.

29. F. Greco, A. Nakajo, Z. Wuillemin, J. Van Herle, ECS Transactions, 2015, 68(1), 1921.
30. Q. Jeangros, A. Faes, J. Hansen, U. Aschauer, J. Van Herle, A. Hessler-Wyser, R. DuninBorlowski, Acta Materialia, 2010, 58, 4578.

31. B. Liu, Y. Zhang, B. Tu, Y. Dong, M. Cheng, J. Power Sources, 2007, 165, 114.

32. M. Ettler, H. Timmermann, A. Weber, N.H. Menzler, J. Power Sources, 2010, 195, 5452.

33. B. Burdin, A. Sheikh, M. Krapchanska, D. Montinaro, R. Spotorno, P. Piccardo, D. Vladikova, ECS Transactions, 2021, 103, 1137. 